\title{
Efficacy of different techniques of AFO construction for hemiplegia patients: A systematic review
}

\author{
Ensieh Pourhosseingholi ${ }^{1}$, Behshid Farahmand ${ }^{1}$, Azam Bagheri*1 $^{1}$, Mohammad Kamali ${ }^{1}$, \\ Morteza Saeb²
}

\begin{abstract}
Background: Ankle foot orthoses (AFOs) are frequently prescribed to improve gait deviation and normalize walking pattern in patients with drop foot hemiplegia disorder. This study was to review the efficacy of different techniques of AFO construction and biomechanics parameters of AFOs. Furthermore, this study aimed to provide a guideline for researchers in detail and help them choose a sufficient measurement instrument.

Methods: Information sources included MEDLINE, CINAHL, Scopus, PubMed, and the Full Cochrane Library up to December 25, 2015. The inclusion criteria include: (1) type and method of controlled clinical trial studies; (2) age of hemiplegia groups (3); AFOs as an intervention; and (4) kinetic and kinematic parameters, and energy expenditure as an intervention of gait performance.

Results: Considering eligibility criteria such as study design, setting, time frame and Language 9 papers with Pedro scores of 5 to 8 for methodological quality were included in the review.

Conclusion: The findings of this review can help to develop guidelines for the best AFO reporting as an intervention and to prevent vagueness of results in the different types of AFOs.
\end{abstract}

Keywords: Adolescent, Hemiplegia, Child, Gait, Orthoses, Brace, Systematic review

Conflicts of Interest: None declared

Funding: None

\section{*This work has been published under CC BY-NC-SA 1.0 license. \\ Copyright $\odot$ Iran University of Medical Sciences}

Cite this article as: Pourhosseingholi E, Farahmand B, Bagheri A, Kamali M, Saeb M. Efficacy of different techniques of AFO construction for hemiplegia patients: A systematic review. Med J Islam Repub Iran. 2019 (3 Jun);33:50. https://doi.org/10.47176/mjiri.33.50

\section{Introduction}

Ankle foot orthoses (AFOs) are the most prescribed interventions to improve gait deviation in patients with drop foot hemiplegia disorder. In this disorder, foot clearance deteriorates during the swing phase leads to poor foot placement at initial contact (1-4). Several studies have investigated the efficacy of AFOs as interventions for improving the kinematic and kinetic of gait in drop foot hemiplegia patients(1,3-4). However, in most of these studies, an ambiguity is seen in selecting mechanical ele-

Corresponding author: Azam Bagheri, bagheri.a@iums.ac.ir

1. Department of Orthotics \& Prosthetics, School of Rehabilitation Sciences, Iran University of Medial Sciences, Tehran, Iran

2. Kermanshah University of Medial Sciences, Kermanshah, Iran ments (3-4). Besides, in some studies, technical efficacy of AFOs in fabrication and test strategy were neither mentioned nor had enough clarity (1). Also, much controversy exists about the AFOs' intervention reliability, validity, clinically relevancy, and outcome measurement which would affect the confidence in prescribing, utilizing and generalizing AFOs (2). As an intervention with sufficient details in trial reports, evaluation of quality of AFOs is highly important (3-5). Although general guidelines exist

\section{$\uparrow$ What is "already known" in this topic:}

Ankle foot orthosis (AFO) is frequently used to improve gait deviations in patients with hemiplegia. AFOs prevent foot drop in the swing phase and promote heel strike in the early stance phase of gait.

\section{$\rightarrow$ What this article adds:}

A variety of studies have reported the AFO is an effective tool for improving the gait pattern of hemiplegia patients. This study provided some guidelines to robustly report AFO interventions, mechanical characteristic of AFOs, and efficacy of AFOs' construction techniques, testing strategies and the outcomes. 
for AFO application as an intervention in clinical, randomized and non-randomized trials (6-9), few studies have dealt with the efficacy of AFOs' intervention guidelines (1-4). Therefore we were set to drive an acceptable, specific, and efficient guideline from the body of the literature. Variable efficacy, which was used in this study, was provided from the body of orthotic literature (3-5).

This study was the first review to specifically concentrate on efficacy reported by AFO intervention studies on hemiplegia and to focus on participants' information, AFOs' interventions, mechanical characteristic of AFOs, and construction and testing strategy and outcomes. Thus, we were set to develop an indicator for assessing and reporting AFOs' detail from the body of literature. The findings of this review should provide a practical and applicable guideline for reporting research results. The proposed guideline should also improve the reporting quality of future AFOs related evidence-based papers and RCT studies.

\section{Methods}

The Cochrane review guideline was used for a comprehensive search strategy (10). Then, electronic databases including MEDLINE, CINAHL, SCOPUS, PubMed, and the full Cochrane Library were searched through for retrieving eligible research. Databases were searched for English articles with no prior exclusions, restrictions, or limitation. The reference list from the relevant identified papers was also searched manually, and gray literatures were not considered. Initially, all English publications between 2000 and 2015 were considered for inclusion; then, following the abstracts, full-text versions of papers were used for further evaluation.

\section{Inclusion criteria}

AFOs' related studies in hemiplegia persons to study resist motion in spastic or paretic drop foot hemiplegia or assist ankle movement by applying force through a threepoint pressure system were selected. Only the randomization related participant (RCT) and experimental works were included, and systematic reviews, case studies, and narrative reviews were excluded.

\section{Data extraction}

The title and abstract of identified studies were assessed by 3 reviewers, $(\mathrm{EP}),(\mathrm{AB})$, and $(\mathrm{BF})$, who were blinded to authors, affiliations, and the publishing journal. At first, the title and abstract of each study was reviewed, then, full text papers were separately evaluated by 3 review team members.

For inclusion or exclusion, each paper was rated using a modified version of the PEDro rating scale with 11 items, assessing the internal validity (Appendix 1) (12). All items scored from one to ten; the first item was related to external validity. Then, all the initially excluded papers were rechecked by the second reviewer (BF) to ensure that they have not been excluded by chance.

Then a full-text reading was planned and again the unfitted articles excluded. To minimize rater error in each criterion, we followed a specific standardized guideline so that up to a satisfactory point.

Hand searching of reference lists were conducted by the same reviewers. According the literature $(3-5,13,14)$, ISPO consensus conference documents $(1,15)$, systematic reviews and checklist guidelines (16), as well as quality checklists previously used in other systematic reviews (17, 18), there was a need for a guideline for technical and detail assessment of AFO. Since our study needed a special quality checklist to provide a systematic assessment of evidence quality a new checklist was designed and adopted using a systematic review of the literature (Table 1). According to the International Classification of Functioning (ICF), there are three main themes to the checklist:

1) Participant information, including denoting type of disease, patients' age, lower limb passive joint range of motion (ROM) and the description of a deformity within the lower limb regarding a pattern of lower limb motion.

2) Mechanical characteristic of AFO and construction, including reporting the aim of the orthotic, type of articulation, range of motion permitting, preventing, or assisting, initial angle of AFO ankle, toe plate length, material type and thickness and trim line, AFO tuning and modification, final angle of shank-to-vertical AFO as angle between the lower leg and vertical while standing in the AFO (19) and custom-made or prefabricated design.

3) Testing strategy, including reporting of the control and test conditions, and details regarding randomization and adaptation and comparing AFO with other modalities. The data extraction and quality assessment to check content and reliability were piloted by both reviewers (EP, $\mathrm{BF})$.

Finally, quality assessment of the quantitative studies were conducted using the EPHPP quality assessment tool

\begin{tabular}{|c|c|c|c|c|c|c|c|c|c|}
\hline Study & $\begin{array}{c}\text { Study } \\
\text { design }\end{array}$ & $\begin{array}{l}\text { Global } \\
\text { quality } \\
\text { rating }\end{array}$ & $\begin{array}{l}\text { Study } \\
\text { design }\end{array}$ & $\begin{array}{l}\text { Protection } \\
\text { against selec- } \\
\text { tion bias }\end{array}$ & $\begin{array}{c}\text { Control for } \\
\text { potential } \\
\text { confounders }\end{array}$ & Blinding $^{\mathrm{a}}$ & $\begin{array}{c}\text { Reliability and } \\
\text { validity of data } \\
\text { collection methods }\end{array}$ & Retention & $\begin{array}{c}\text { PEDro } \\
\text { score }\end{array}$ \\
\hline $\begin{array}{l}\text { Bucken et al } 2004 \\
\text { (24) }\end{array}$ & RCT & Strong & Strong & Strong & Strong & Moderate & Moderate & Strong & $8 / 10$ \\
\hline Sienko 2002 (37) & $\mathrm{RCT}$ & Strong & Strong & Moderate & Strong & Moderate & Moderate & Weak & $7 / 10$ \\
\hline $\begin{array}{l}\text { Thompson } 2002 \\
\text { (25) }\end{array}$ & $\mathrm{RCT}$ & Strong & Moderate & Strong & Moderate & Weak & Moderate & weak & $6 / 10$ \\
\hline $\begin{array}{l}\text { Desloovere/ Vang- } \\
\text { estul } 2008 \text { (3) }\end{array}$ & $\mathrm{RCT}$ & Moderate & Moderate & Weak & Weak & Weak & Moderate & Weak & $5 / 10$ \\
\hline $\begin{array}{l}\text { Brehm, Merel- } \\
\text { Anne } 2008 \text { (48) }\end{array}$ & RCT & Moderate & Moderate & Weak & Moderate & weak & Moderate & Weak & $5 / 10$ \\
\hline $\begin{array}{l}\text { Vangestal } 2008 \\
\text { (31) }\end{array}$ & RCT & Moderate & Moderate & Weak & Weak & Moderate & Moderate & Moderate & $6 / 10$ \\
\hline
\end{tabular}




\begin{tabular}{|c|c|c|c|c|c|c|c|c|c|}
\hline Study & $\begin{array}{l}\text { Study } \\
\text { design }\end{array}$ & $\begin{array}{l}\text { Global } \\
\text { quality } \\
\text { rating }\end{array}$ & $\begin{array}{l}\text { Study } \\
\text { design }\end{array}$ & $\begin{array}{l}\text { Protection } \\
\text { against selec- } \\
\text { tion bias }\end{array}$ & $\begin{array}{c}\text { Control for } \\
\text { potential } \\
\text { confounders }\end{array}$ & Blinding $^{\mathrm{a}}$ & $\begin{array}{c}\text { Reliability and } \\
\text { validity of data } \\
\text { collection methods }\end{array}$ & Retention & $\begin{array}{c}\text { PEDro } \\
\text { score }\end{array}$ \\
\hline $\begin{array}{l}\text { Bregman, Daa R } \\
\text { (1) }\end{array}$ & $\mathrm{RCT}$ & Strong & Strong & Strong & Strong & Moderate & Moderate & Moderate & $7 / 10$ \\
\hline Cakar E 2010 (51) & $\mathrm{RCT}$ & Weak & Moderate & Weak & Weak & Moderate & Weak & Moderate & $5 / 10$ \\
\hline Kerkum 2014 (52) & $\mathrm{RCT}$ & Strong & Moderate & Moderate & Moderate & Moderate & Strong & Moderate & $7 / 10$ \\
\hline
\end{tabular}

(Table 1).

\section{Results}

The screening phase yielded 178 abstracts, and 34 articles and hand searching led to 189 papers (Fig. 1). After a full-text review of 189 titles 41 articles were found to be eligible that were included in this review. Ultimately, 9 studies were included for qualitative analysis and evidence synthesis.

Table 2 depicts the demographic characteristics of participants, sample size of the study, clinical diagnosis, type of interventions, characteristic of control group, study design and preliminary outcome measurement. Most articles evaluated kinetic or kinematic of the gait whereas walking on a level surface. Others evaluated balance or energy consumption.

Table 3 gives an outline of the data extraction and quality results over all studies.

\section{Mechanical characteristic of AFOs and construction}

Mechanical approach was applied to confirm the effectiveness of AFOs interventions and to pursue gait measurements at the level of body functions and structures (3, 6-10, 24, 30-34). Assessment of AFOs interventions at the level of kinematics and kinetics at the ankle joint and proximal joints may be considered as a tool for checking the quality of the AFO intervention itself. This reveals the primitive effect of an AFO on the ankle and foot function (24). Outcome measures from gait analysis, either broad indexes or particular joint measures, represent a shift towards normality and can thus be noted relevant to confirm effectiveness of AFO interventions (30-34). At last, nine studies clearly stated the AFOs ankle angle and the position of leg during casting or Scanning process, which were synthesized in this study.

AFOs' modification caused significant positive biomechanical effects at drop foot hemiplegia studies. Materials and other details related to the thickness or process of manufacturing were mentioned in this paper. Custommade devices were most commonly tested (Table 3), however, in some articles the process of fabricating was ambiguous or not mentioned. AFO fitting of the patients was not mentioned in reviewed articles. A follow-up measure was not conducted in any reviewed paper in this study.

\section{Testing strategy and outcome measure}

Most studies used a randomized clinical trial (Table 4) than non-random study. Remaining studies either did not report type of their study or it seems to be ambiguous. Weaning time was also considered as a part of the strategy

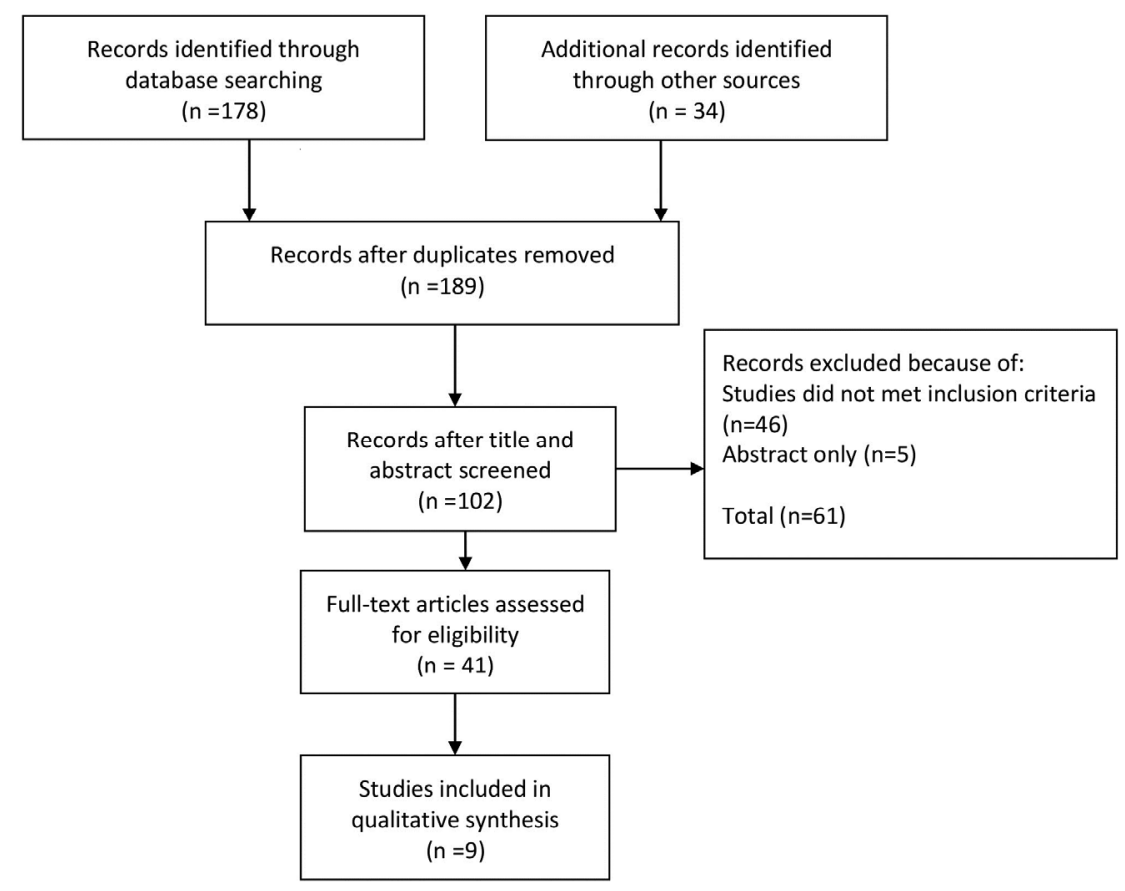

Fig. 1. Flow of study selection 
Table 2. Details of the included studies

\begin{tabular}{|c|c|c|c|c|c|c|c|}
\hline Author & & Sample size & $\begin{array}{c}\text { Participant } \\
\text { characteristics }\end{array}$ & $\begin{array}{l}\text { Intervention(s) vs } \\
\text { control condition }\end{array}$ & Procedure & $\begin{array}{l}\text { Outcome } \\
\text { measures }\end{array}$ & Result and conclusion \\
\hline $\begin{array}{l}\text { Buckon et al, } \\
2001 \text { (24) }\end{array}$ & 16 & $\begin{array}{l}\text { spastic diplegia } \\
10 \text { males } 6 \\
\text { females; mean } \\
\text { age } 8 \text { y } 4 \\
\text { M; range } 4 \\
\text { years } 4 \text { M- } 11 \\
\text { y } 6 \mathrm{M} \\
4 \text { children were } \\
\text { classified at } \\
\text { level I of the } \\
\text { Gross Motor } \\
\text { Function Clas- } \\
\text { sification Sys- } \\
\text { tem, } \\
\text { the remaining } \\
12 \text { were at level } \\
\text { II }\end{array}$ & $\begin{array}{l}\text { posterior leaf } \\
\text { spring (PLS), } \\
+ \\
\text { hinged ankle-- } \\
\text { foot } \\
\text { orthosis } \\
+ \\
\text { solid } \\
\text { ankle-foot } \\
\text { orthosis } \\
\text { Vs: barefoot } \\
\text { (b f). }\end{array}$ & $\begin{array}{l}\text { There are four } \\
\text { visits for Each } \\
\text { child: an standard } \\
\text { assessment, af- } \\
\text { ter3months of no } \\
\text { AFO wear, and an } \\
\text { evaluation at the } \\
\text { end of each } \\
\text { AFO three-month } \\
\text { wearing measured } \\
\text { by gait analysis }\end{array}$ & \multicolumn{2}{|c|}{$\begin{array}{l}\text { Three-dimensional } \\
\text { kinematic and kinetic } \\
\text { gait data at the pelvis, } \\
\text { hip, knee, and ankle } \\
\text {, energy expenditure, } \\
\text { and functional motor } \\
\text { skills(Upper extremity } \\
\text { function, Gross motor } \\
\text { function and perfor- } \\
\text { mance) }\end{array}$} & $\begin{array}{l}\text { AFO use, regardless of configuration, did not } \\
\text { significantly alter pelvic and hip kinematics } \\
\text { and/or kinetics from the BF condition. A the } \\
\text { knee there was no significant kinematic change. } \\
\text { one kinetic variable (peak knee extensor mo- } \\
\text { ment in early stance) was significantly } \\
(\mathrm{p}=0.007 \text { ) increased in the HAFO configuration } \\
\text { compared with BF. All AFO configurations } \\
\text { significantly altered ankle kinematics during } \\
\text { the stance and swing phases. } \\
\text { All of the AFO configurations significantly } \\
\text { increased step ( }<0.005) \text { and stride length } \\
\text { ( }<0.006) \text { compared with BF, while significant- } \\
\text { ly decreasing cadence }(\mathrm{p}<0.0005) \text {. } \\
\text { Energy cost (mLO2 } / \mathrm{kg} / \mathrm{m}) \text { was significantly } \\
\text { decreased in self-selected and fast walking in } \\
\text { all AFO configurations compared with baseline } \\
(\mathrm{p}<0.003) \text {. }\end{array}$ \\
\hline $\begin{array}{l}\text { Susan Sienko } \\
\text { Thomas et al } \\
2002 \text { (37) }\end{array}$ & 19 & $\begin{array}{l}19 \text { children } \\
\text { with spastic } \\
\text { hemiplegia } \\
11 \text { males }+8 \\
\text { females ,mean } \\
\text { age : } 9+3 \\
\text { years (range } 6- \\
15 \text { years and } \\
\text { mean weight : } \\
34.7 \mathrm{~kg}\end{array}$ & $\begin{array}{c}\text { barefoot and } \\
\text { hinged, poste- } \\
\text { rior leaf } \\
\text { spring (PLS) } \\
\text { and solid AFO }\end{array}$ & $\begin{array}{c}\text { Children were } \\
\text { evaluated barefoot } \\
\text { (first } 3 \text { months) } \\
\text { and } \\
\text { with a hinged PLS } \\
\text { and solid AFO } \\
\text { (each AFO for } 3 \\
\text { months) during } \\
\text { stair ascent and } \\
\text { descent. a motion } \\
\text { analysis system } \\
\text { was used to } \\
\text { measure kinemat- } \\
\text { ics. }\end{array}$ & \multicolumn{2}{|c|}{$\begin{array}{l}\text { Kinematic data for stair } \\
\text { locomotion }\end{array}$} & $\begin{array}{l}\text { Kinematics: The hinged AFO allowed signifi- } \\
\text { cantly greater dorsiflexion }\left(16^{\circ}\right) \text { during stance } \\
\text { than barefoot }\left(10^{\circ}, \mathrm{P}\right. \\
0.0007) \text { and the solid AFO }\left(9^{\circ}, \mathrm{P}=0.0002\right) \\
\text { configuration. Dorsiflexion during swing was } \\
\text { significantly greater for the hinged }\left(14^{\circ}\right) \text { and } \\
\text { PLS }\left(10^{\circ}\right) \text { AFOs in comparison to barefoot } \\
\text { Conclusion: AFOs do not inhibit the ability of } \\
\text { the child with spastic hemiplegia to ascend and } \\
\text { descend stairs. All AFOs improved the foot } \\
\text { contact position during stair ascent. }\end{array}$ \\
\hline $\begin{array}{l}\text { Thompson } \\
\text { (25) }\end{array}$ & 18 & $\begin{array}{l}\text { hemiplegia, } \\
8 \text { females and } \\
10 \text { males } \\
\text {, mean age } 8 \text { y } \\
5 \mathrm{~m} \\
\text { (range } 5 \text { y } 8 \mathrm{~m} \\
\text { to } 11 \text { y) } \\
\text { Patients usually } \\
\text { walk wearing a } \\
\text { rigid polypro- } \\
\text { pylene AFO }\end{array}$ & $\begin{array}{l}\text { Custom made } \\
\text { rigid AFO }\end{array}$ & $\begin{array}{l}\text { Children evaluated } \\
\text { by gait analysis } \\
\text { using a six camera } \\
\text { Vicon and muscu- } \\
\text { loskeletal } \\
\text { modelling using } \\
\text { specially designed } \\
\text { software( first bare } \\
\text { foot Then with } \\
\text { AFO) }\end{array}$ & \multicolumn{2}{|c|}{$\begin{array}{c}\text { temporal/spatial pa- } \\
\text { rameters } \\
\text { knee and ankle kine- } \\
\text { matics } \\
\text { hamstring length }\end{array}$} & $\begin{array}{l}\text { With AFO: There were significant increases in } \\
\text { cadence, step length, and walking velocity with } \\
\text { significant improvements in knee kinematics. } \\
\text { At the ankle the expected decrease in ankle } \\
\text { motion and significantly improved ankle dorsi- } \\
\text { flexion } \\
\text { at initial contact and stance were observed } \\
\text { Conclusion: pathological gait patterns } \\
\text { in CP are reflected in measurements of maxi- } \\
\text { mum muscle length during the gait cycle. }\end{array}$ \\
\hline $\begin{array}{l}\text { Desloovere/ } \\
2008(3)\end{array}$ & 15 & $\begin{array}{l}\text { children diag- } \\
\text { nosed with } \\
\text { hemiplegia, } \\
\text { mean age: } \\
5.86 \text { years } \\
(1.76), 8 \text { chil- } \\
\text { dren had right, } \\
\text { and } 7 \\
\text { children had } \\
\text { left side in- } \\
\text { volvement. }\end{array}$ & $\begin{array}{c}\text { Common } \\
\text { PLS+ Dual } \\
\text { Carbon Fiber } \\
\text { Spring AFO } \\
\text { (CFO) }\end{array}$ & $\begin{array}{l}\text { Walking of Chil- } \\
\text { dren tested in } 4 \\
\text { conditions at ran- } \\
\text { dom order: bare- } \\
\text { foot, shoes only, } \\
\text { with PLS and CFO } \\
\text { combined with } \\
\text { shoes } \\
\text { Kinematic } \\
\text { evaluation was } \\
\text { done using an } \\
\text { eight-camera } \\
\text { VICON } \\
\text { system }\end{array}$ & \multicolumn{2}{|c|}{$\begin{array}{l}\text { Spatio-temporal pa- } \\
\text { rameters, } \\
\text { Kinematics, kinetics at } \\
\text { ankle, knee, hip joint }\end{array}$} & $\begin{array}{l}\text { cadence significantly improved in shoes com- } \\
\text { pared to barefoot. At ankle level: significant } \\
\text { increased range of motion and angular velocity } \\
\text { during push-off. Increased knee shock absorp- } \\
\text { tion, knee flexion in swing and maximal knee } \\
\text { extension moment in stance. Finally, mean } \\
\text { coronal hip angle in swing, mean pelvic obliq- } \\
\text { uity, and maximal hip power absorption in } \\
\text { stance were significantly increased in shoes } \\
\text { when compared to barefoot }(\mathrm{P}<0.01 \text { ). Walking } \\
\text { velocity and step length increased in both or- } \\
\text { thotic conditions when compare d to barefoot } \\
\text { conclusion, both orthoses successfully im- } \\
\text { proved gait patterns, but push-off at the ankle } \\
\text { significantly improved when the CFO was } \\
\text { compared to the PLS }\end{array}$ \\
\hline
\end{tabular}

for new or unfamiliar devices. Most studies clearly utilized the control group, the barefoot condition was the most common type of control followed by wearing shoes and both barefoot and with shoes.

This review identified full papers which evaluated the effect of AFOs on the different range of outcome measures in hemiplegia patients with considerable varieties in various study strategies. In many cases this posed limits for assessment of intervention quality and deteriorated the findings.

\section{Type of measurement}

Computerized 3D gait analysis with or without force plate were used as a useful method of evaluating gait in hemiplegic patients with AFO (12). Kinetic and kinematic data derived from these studies may be considered as a 
Table 2. Ctd

Brehm et a 2008 (48)

181

110 boys and 71
girls with spastic
cerebral palsy:
mean age 9
years (range
$4.6-18.4$ ) 23
hemiplegia, 103
diplegia,

55 quadriplegia

\section{Barefoot +}

shoe+

Solid AFO

+shoe PLS

\section{sis of gait, was done along \\ sis of gait, was done a
a $10-\mathrm{m}$ walkway. \\ oxygen consumption \\ measured by a breath-by- \\ breath gas-analysis sys-}

\section{Oxygen consump- \\ tion Speed and \\ GGI (activity)}

Speed improved significantly by $8.2 \%$ with solid AFO $(\mathrm{P}<0.001)$. Cost of walking was $6 \%$ lower with AFO $(\mathrm{P}=0.007)$ (a significant decrease in cost of walking for PLS walking $(8 \%)$, whereas for solid AFO, walking remained unchanged). The GGI remained unchanged $(\mathrm{P}=0.607)$. Changes in minimum knee flexion angle in stance phase and in terminal swing $(\mathrm{P}=0.013$ and $\mathrm{P}=0.022$, respectively) Conclusion: AFO significantly decreased the energy cost of walking of quadriplegic children with $\mathrm{CP}$, compared with barefoot walking, but remained unchanged with hemiplegic and diplegic CP The Upper Limb Coordination $(\mathrm{p}<0.003) \quad$ and Upper-Limb Speed and Dexterity $(\mathrm{p}<0.016)$ subtests were significantly improved in all AFO configurations compared with $\mathrm{BF}$, with no significant difference between AFO configurations

Conclusion :AFO use enhances the functional abilities of most children with spastic diplegia

$\begin{array}{ccc}\begin{array}{l}\text { Van Gestel et } \\ \text { al 2008 (31) }\end{array} & \begin{array}{c}\text { Children with } \\ \text { hemiplegia: } 15\end{array} & \begin{array}{c}\text { PLS CFO } \\ \text { (Dual Carbon }\end{array} \\ & \text { boys, 22 girls, } & \text { Fiber Spring } \\ \text { mean age: } 8.5 & \text { AFO) Orteams } \\ 2.8 \text { years (range } & \text { (orthoses with } \\ 4-10 \text { years) } & \text { the dorsal part } \\ \text { GMFCS Level: I } & \text { containing 11 } \\ & \text { and II } & \text { sleeves) Bare- } \\ & & \text { foot }\end{array}$

Walking of Children measured and compared by gait analysis, including 3- D kinematics and kinetics in 4 conditions: barefoot, and with 3 types of AFOs
Stride temporal Kinematics, and lower limb moment (body function and structure) Gait speed GMFCS (activity)

\begin{tabular}{|c|c|c|c|c|}
\hline $\begin{array}{l}\text { Bregman } 2008 \\
\text { (1) }\end{array}$ & 7 & $\begin{array}{l}4 \text { stroke patiens } \\
\text { (1 right side, } 3 \\
\text { left side) } \\
3 \text { MS paients( } 2 \\
\text { right side, } 1 \text { lef } \\
\text { side) }\end{array}$ & $\begin{array}{l}\text { Three AFOs } \\
\text { were of the } \\
\text { type Dynafo } \\
\text { (Maramed } \\
\text { Orthopaedic } \\
\text { Systems, Hia- } \\
\text { leah, FL, } \\
\text { USA), and four } \\
\text { AFOs were of } \\
\text { the type } \\
\text { 298 D. J. J. } \\
\text { Bregman et al. } \\
\text { Orteam }\end{array}$ & $\begin{array}{l}\text { Patients walked with } \\
\text { shoes only, and with both } \\
\text { shoes and AFO,3-D gait } \\
\text { analysis was performed. } \\
\text { The balance without AFO } \\
\text { was evaluated using the } \\
\text { Berg Balance scale, the } \\
\text { spasticity of the gas- } \\
\text { trocnemius and soleus } \\
\text { was evaluated using the } \\
\text { Spasticity Test (SPAT). } \\
\text { energy consumption was } \\
\text { measured. }\end{array}$ \\
\hline $\begin{array}{l}\text { Cakar } 2010 \\
(51)\end{array}$ & 25 & $\begin{array}{c}\text { Spastic hemi } \\
\text { paretic post } \\
\text { stroke patients } \\
17 \text { male } \\
8 \text { female } \\
\text { Mean age: } 60.52 \\
\text { (range: } 35-80 \text { ) }\end{array}$ & $\begin{array}{l}\text { Prefabricated } \\
\text { PLS with } \\
\text { footwear }\end{array}$ & $\begin{array}{l}\text { Patients were instructed to } \\
\text { regulary use PLS with } \\
\text { footwear. Balance and fall } \\
\text { risk were evaluated a } \\
\text { week later }\end{array}$ \\
\hline $\begin{array}{l}\text { Kerkum } 2015 \\
(52)\end{array}$ & 15 & $\begin{array}{c}\text { Spastic CP } \\
\text { children } \\
11 \text { boys } \\
4 \text { girls } \\
\text { aged between } 6 \\
\text { and } 14 \text { years old }\end{array}$ & $\begin{array}{l}\text { Shoe only vs } \\
\text { ventral shell } \\
\text { spring-hinged } \\
\text { AFO(three } \\
\text { configuration } \\
\text { stiffness) }\end{array}$ & $\begin{array}{l}\text { In order to acclimatization } \\
\text {,each vAFO stiffness } \\
\text { configuration was worn } \\
\text { for a period of four weeks } \\
\text {, after which efficacy of } \\
\text { that vAFO was assessed } \\
\text { using 3d gait analysis and } \\
\text { a 6-minute walk test to } \\
\text { measure walking energy }\end{array}$ \\
\hline
\end{tabular}

Cadence significantly decreased and step length and walking velocity significantly increased with orthoses (all $\mathrm{P}=0.001$ ). Knee range of motion during shock absorption, swing kinematics, and most knee kinetics also significantly changed $(\mathrm{P}=$ 0.001-0.004). About half of the hip kinematics showed a significant effect of orthoses and all hip moment and power were significantly increased $(\mathrm{P}$ $=0.001-0.006)$. Only the CFO could significantly improve ankle dorsiflexion at loading response vs the barefoot condition ( $\mathrm{P}=0.007)$ Conclusion: although the PLS ensured the highest correction at the ankle around initial contact, the CFO created a significantly higher maximal hip flexion moment in stance

Energy Cost of walking Ankle Kinematis ankle kinetics

Berg balance scale Postural and fall risk test of BIO-

DEX balance system

Walking energy cost daily activity, gait biomechanics
There was a significant decrease of $12.1 \%(+$ 10.6) in EC of walking when patients walked with the AFO. The AFO changed the ankle joint kinematics in the benefit group. The AFO did not change the ankle joint moment

Conclusion: he authors found a clear link between the mechanical effect and the energetic functional effects of the AFO

No statistically significant change in any of the PST scores by use of pls Conclusion: prefabricated PLS improved balance and reduced fall risk useful predictor of efficiency of AFO. Beside the gait analysis, energy consumption as a method for evaluating effective output of gait was used in some studies. For detailed study of mechanical property of AFO BRUCE device was used as an acceptable method. Ethical approval as necessary part of each study was considered in all papers included the current study (20).

\section{Discussion}

In this systematic review, nine full papers using AFO in 


\begin{tabular}{|c|c|c|c|c|c|c|c|}
\hline Author & $\begin{array}{c}\text { AFO } \\
\text { movement }\end{array}$ & AFO angle & Toe plate & Material & Type of AFO & $\begin{array}{c}\text { Type } \\
\text { of fabrication }\end{array}$ & Alignment \\
\hline Buckon et all, 2001 (24) & $\sqrt{ }$ & $\sqrt{ }$ & Full length & $\sqrt{ }$ & SAFO & Custom & $\sqrt{ }$ \\
\hline Susan Sienko Thomas et all 2002 (37) & $\sqrt{ }$ & $\sqrt{ }$ & $3 / 4$ full & $\sqrt{ }$ & PLS & Custom & $\sqrt{ }$ \\
\hline Thompson (25) & $\sqrt{ }$ & - & Full & - & SAFO & Custom & $\sqrt{ }$ \\
\hline Desloovere 2008 (3) & $\sqrt{ }$ & - & Full & - & SAFO & Custom & $\sqrt{ }$ \\
\hline Brehm et al., 2008 (48) & - & - & Full & - & PLS & - & - \\
\hline Van Gestel et al., 2008 (31) & $\sqrt{ }$ & - & Full & $\sqrt{ }$ & PLS & Prefab. & - \\
\hline Bregman 2008 (1) & $\sqrt{ }$ & $\sqrt{ }$ & Full & $\sqrt{ }$ & DAFO & Prefab. & - \\
\hline Cakar $2010(51)$ & $\sqrt{ }$ & $\sqrt{ }$ & Full & $\sqrt{ }$ & PLS & Prefab. & - \\
\hline Kerkum 2015 (52) & $\sqrt{ }$ & $\sqrt{ }$ & Full & $\sqrt{ }$ & hingAFO & Custom & $\sqrt{ }$ \\
\hline \multicolumn{8}{|c|}{ Table 4. Testing strategy and outcome measure } \\
\hline Author & Study design & \multicolumn{2}{|c|}{ Orthotic aim } & Method & \multicolumn{3}{|c|}{$\begin{array}{l}\text { Outcome } \\
\text { Measure }\end{array}$} \\
\hline Buckon et all, 2001 (24) & Prospect & \multicolumn{2}{|c|}{-} & Clinical trial & \multicolumn{3}{|c|}{$\begin{array}{l}\text { Kinematic/energy cost } \\
\text { Energy }\end{array}$} \\
\hline Susan Sienko Thomas et all 2002 (37) & Prospect & \multicolumn{2}{|c|}{ Ambiguous } & Clinical trial & \multicolumn{3}{|c|}{$\begin{array}{l}\text { Kinematic } \\
\text { Kinematic }\end{array}$} \\
\hline Thompson (25) & Prospect & \multicolumn{2}{|c|}{ Clear } & Clinical trial & \multicolumn{3}{|c|}{ Kinematic/kinetic } \\
\hline Desloovere 2008 (3) & Prospect & \multicolumn{2}{|c|}{ Clear } & Clinical trial & \multicolumn{3}{|c|}{ Kinematic/kinetic } \\
\hline Brehm et al., 2008 (48) & Prospect & \multicolumn{2}{|c|}{ Clear } & Clinical trial & \multicolumn{3}{|c|}{ Energy cost / walking efficacy } \\
\hline Van Gestel et al., 2008 (31) & Prospect & \multicolumn{2}{|c|}{ Clear } & Clinical trial & \multicolumn{3}{|c|}{ Kinematic/kinetic } \\
\hline Bregman 2008 (1) & Prospect & \multicolumn{2}{|c|}{ Clear } & Clinical trial & \multicolumn{3}{|c|}{ Functional effect /mechanical properties } \\
\hline Cakar $2010(51)$ & Prospect & \multicolumn{2}{|c|}{ Clear } & Clinical trial & \multicolumn{3}{|c|}{ Balance/postural stability } \\
\hline Kerkum 2015 (52) & prospect & \multicolumn{2}{|c|}{ Clear } & Clinical trial & \multicolumn{3}{|c|}{ Mechanical properties } \\
\hline
\end{tabular}

drop foot hemiplegia were analyzed. In agreement with previous reviews $(4,5)$ there was considerable variety in the quality of efficiency details and techniques of AFOs (1-4) that posed limits to efficiency evaluation and maintaining confidence of findings. This variability and incomplete reporting of data further reduces the usability of the finding in meta-analysis $(4,5)$.

In this review we tried to explore each phases of RCTs (21) to assess the efficacy of design and fabrication of AFOs in drop foot hemiplegia. Thus, probable benefits of any priority in clinicians' decision making may lead to improve the prescription (22).

The level of activity was considered as the most relevant outcome parameter of the ankle $(21,23)$ which quantifies walking ability and the level of the need of a patient for the potential benefit of orthotic treatment. Walking performance, i.e., walking in daily life, Stability (safety), walking speed, walking economy (PCI, EC and oxygen uptake) and dynamic stability $(25-27,24,30,31)$ fairly determined the different aspect of patients' problems and needs (21-23).

Some studies were subdivided their participants according to level of pelagic condition, gait pattern, and differences in outcomes between the different types of AFO $(23,24,30,31)$. As a result, differences in outcome measures and type of AFOs used in drop foot hemiplegia have obliged researchers to concentrate on participant groups, which is a degree of homogeneity regarding gait pattern. Also, these differences sometimes led to variety in sub-dividing including age of participants and type and severity of the disorder (27). For instance, we found some studies which concentrated either on different groups according to gait pattern or particular gait abnormalities (21, $23,24,25,28)$.

Several other studies ensured homogeneity by describing knee and ankle posture either with $(21,23)(24,25$, 28) (29-32) or without reference to published gait classifi- cation systems (39). Several other studies used knee and ankle posture to subdivide participants' gait classification systems (39) with and without references (38).

Another source of homogeneity is the design and construction of the AFOs that as an essential part of hemiplegic research should be clarified (33). It showed differences between AFOs and diversity in spatiotemporal parameters (33-35), ankle and knee and hip kinematics (3, 24, 34-36) as outcomes in straight line walking and stair ascent and descent as well as doing some reach tasks $(37,23)$.

It seems that AFOs with a positive influence to align the joints of drop foot hemiplegia lead to improve kinematic variable such as in cadence and gait velocity (23).

Regarding adaptation time with AFOs, a tendency toward improvement in kinematic parameters like speed of walking and cadence was found (38-40). All types of AFOs led to significant improvement in walking speed in comparison to control groups. However, different studies were reported different results for cadence with and without AFOs, and majority of studies reported increase in speed of walking. As cadence is the number of steps per certain time, some patients showed increase in speed of walking without any changes in steps per minute (1-4).

The AFO alignment is described by the AFO ankle angle in respect to leg which considered in casting process. In such cases the ankle dorsiflexion only occurred with knee extension $(14,19,32,38)$.

Combination of the AFO with shoes may alter the angle between shank and foot which was deteriorated the alignment of the AFOs relative to vertical angle especially while difference was existed between the height of the heel and forefoot $(19,32,38,39,40)$. Differences in shank-to-vertical angle because of shoes have been showed to increase the efficacy of the alignment of the ground reaction force (GRF) during standing. Modification of this angle could be due to improving of GRF orientation during walking $(14,19,32,40-45)$. 
As it is revealed from evidence individual alignment and modifying of every AFO may help preventing inappropriate SVA angle to obtain optimal outcome (19). However, AFO modification was not a new concept but recently it seems to be considerable as a part of improving the function of hemiplegia $(3,31,32,39,40)$. In order to overcome this limitation, the shank-to-vertical angle is described as criteria for the alignment of the AFO and footwear- orthosis should be considered in casting process $(3,31,32,39,46-48)$.

For better function, the foot section stiffness of the AFOs in addition of the shoes frequently provides the firm lever arm. As a result, shoes as a part of the orthotic intervention determined the neutral angle of the AFO and the inclination of the tibia $(33,48)$. This combination is obtained by adding the heel height of the shoes to arrive at the optimal tibia inclination $(47,49)$. This inclination angle was achieved by measuring net moment of the hip and knee joints $(3,31,32,39,47,49)$. To our knowledge, only one study has examined the effect of different AFO toeplate lengths in hemiplegic post-stroke adults (38). The result of this study reported significant differences in the amount of dorsiflexion at the stance phase.

Some studies in this review clearly reported that AFO was used to resist the ankle foot unwanted movement, depending on structure and mechanical properties such as trim line position and material properties. Vast majority of material properties used in fabrication of the AFOs may also influence the flexibility of these devices and the mobility of the ankle and metatarsophalangeal joints (38). Despite suitable examples $(21,24,35,41,42)$, detailed technical points in AFO design were missed in some studies $(43,44,47,49)$. Using newly designed method for measuring AFOs stiffness with approved reliability and clinical applicability $(48,50)$ has recently been described.

To enhance AFO intervention results, they must be more accurately assessed regarding the design. Further work should be done on the movements prevented, assisted and permitted by the AFO design like mechanical articulation or special trim line, toe plate form and length and flexibility $(21,24,35,41,42)$, materials and method of fabrication, AFO ankle angling combination with SVA angle with shoes, type of shoes worn and details of any modifying in AFOs.

Clear reporting of technical aspect of AFOs in every study helps to understand the variables that may affect AFOs as an intervention (44-45). In current study only a randomized trial paper was chosen as it eliminated bias resulting from the order of testing (45) and is particularly important in orthotic research as there are usually two or more conditions being compared over repeated trials of tasks such as walking.

Nonrandomized order of testing introduces the risk of fatigue in the tasks performed last and not used as a usual method in orthotic intervention, except in retrospective analysis.

All reviewed studies were performed in barefoot or shod with and without AFOs. We included both barefoot and shod conditions. According to these studies, shoes alone could have either a negative or positive effect on gait pa- rameters in the section of SVA (46). Weaning time is needed to adapt with an unfamiliar device which ensuring researcher that the effects of the device accurately represent daily use. Most of these studies were followed at least one week and only one study was conducted in less than one day $(36,42)$.

\section{Future research}

We tried to emphasize on improving the quality of the body of literature. Furthermore, we tried to present a systematic and detailed approach for reporting the participant's demographics, the AFO intervention and testing strategies. This review has raised several questions and provided their answers. For example, what is the most appropriate control condition for comparison with an AFO intervention? What is the minimum weaning required for an unfamiliar device? Do small differences in AFO design; stiffness and alignment have a significant effect on AFO effectiveness? Answering these questions might facilitate comparison of already published studies. These are in line with suggestions arising from the recent International Society for Prosthetics and Orthotics (ISPO) consensus conferences on the orthotic management of on CP (47) and stroke (15). Finally, future studies should aim to identify the most relevant biomechanical parameters for gait analysis in drop foot hemiplegia for better guideline designing.

\section{Limitations}

Although this study provides some guideline for AFO prescription, there are still a lot of unraised questions about the different aspects of the best AFO design and the duration of AFO usage.

\section{Conclusion}

This study tried to construct a robust guideline for reporting the details of AFO as an intervention (7). The guideline should also be helpful for future investigations in other areas and may improve the synthesis of quantitative research.

\section{Conflict of Interests}

The authors declare that they have no competing interests.

\section{References}

1. Bregman DJ, De Groot V, Van Diggele P, Meulman H, Houdijk H, Harlaar J. Polypropylene ankle foot orthoses to overcome drop-foot gait in central neurological patients: a mechanical and functional evaluation. Prosthet Orthot Int. 2010;34(3):293-304

2. Tyson SF, Thornton HA. The effect of a hinged ankle foot orthosis on hemiplegic gait: objective measures and users' opinions. Clin Rehabil. 2001 Feb;15(1):53-8

3. Desloovere K, Molenaers G, Van Gestel L, Huenaerts C, Van Campenhout A, Callewaert B, et al. How can push-off be preserved during use of an ankle foot orthosis in children with hemiplegia? A prospective controlled study. Gait Posture. 2006;24(2):142-51.

4. Figueiredo EM, Ferreira GB, Moreira RCM, Kirkwood RN, Fetters L. Efficacy of ankle-foot orthoses on gait of children with cerebral palsy: systematic review of literature. Pediatr Phys Ther. 2008;20(3):207-23.

5. Morris C. A review of the efficacy of lower-limb orthoses used for cerebral palsy. Dev Med Child Neurol. 2002;44(3):205-11. 
6. Moher D, Schulz KF, Altman DG. The CONSORT statement: revised recommendations for improving the quality of reports of parallel group randomized trials. BMC Med Res Methodol. 2001;1(1):2.

7. Des Jarlais DC, Lyles C, Crepaz N. Improving the reporting quality of nonrandomized evaluations of behavioral and public health interventions: the TREND statement. Am J Public Health Res. 2004:94(3):361-6.

8. Mayo-Wilson E. Reporting implementation in randomized trials: proposed additions to the consolidated standards of reporting trials statement. Am J Public Health Res. 2007;97(4):630.

9. Boutron I, Moher D, Altman DG, Schulz KF, Ravaud P. Extending the CONSORT statement to randomized trials of nonpharmacologic treatment: explanation and elaboration. Ann Intern Med. 2008;148(4):295-309.

10. Alderson P, Green S, Higgins J. Cochrane reviewers' handbook 4.2. 2 [updated March 2004]. Cochrane Libr. 2004;1:1-59.

11. Collins N, Bisset L, McPoil T, Vicenzino B. Foot orthoses in lower limb overuse conditions: a systematic review and meta-analysis. Foot Ankle Int. 2007;28(3):396-412.

12. Herbert RD, Bø K. Analysis of quality of interventions in systematic reviews. Br Med J. 2005;331(7515):507.

13. Teplicky R, Law M, Russell D. The effectiveness of casts, orthoses, and splints for children with neurological disorders. Infants Young Child. 2002;15(1):42-50.

14. Bowers R. Establishing evidence based practice in the orthotic management of stroke. J Prosthet Orthot. 2007.

15. Condie E, Campbell JN, Martina J. Prosthetics ISf, Orthotic Report of a consensus conference on the orthotics management of stroke patients: held at Avegoor Conference Centre, Ellecom, Netherlands, 21st-26th September 2003. Prosthet Orthot Int. 2004.

16. Oxman AD. Checklists for review articles. $\mathrm{Br}$ Med J. 1994;309(6955):648.

17. Dobson F, Morris ME, Baker R, Graham HK. Gait classification in children with cerebral palsy: a systematic review. Gait Posture. 2007;25(1):140-52.

18. Hijmans JM, Geertzen JH, Dijkstra PU, Postema K. A systematic review of the effects of shoes and other ankle or foot appliances on balance in older people and people with peripheral nervous system disorders. Gait Posture. 2007;25(2):316-23.

19. Owen E. Shank angle to floor measures and tuning of ankle-foot orthosis footwear combinations for children with cerebral palsy, spina bifida and other conditions. Glasgow: University of Strathclyde. 2004.

20. Ferreira LAB, Neto HP, Grecco LAC, Christovão TCL, Duarte NA, Lazzari RD, et al. Effect of ankle-foot orthosis on gait velocity and cadence of stroke patients: a systematic review. J Phys Ther Sci. 2013;25(11):1503.

21. Campbell M, Fitzpatrick R, Haines A, Kinmonth AL, Sandercock P, Spiegelhalter D, et al. Framework for design and evaluation of complex interventions to improve health. Bmj. 2000;321(7262):694-6.

22. Bowers R, Ross K. Development of a best practice statement on the use of ankle-foot orthoses following stroke in Scotland. Prosthet Orthot Int. 2010;34(3):245-53.

23. Abel MF, Juhl GA, Vaughan CL, Damiano DL. Gait assessment of fixed ankle-foot orthoses in children with spastic diplegia. Arch Phys Med Rehabil. 1998;79(2):126-33.

24. Buckon CE, Thomas SS, Jakobson-Huston S, Sussman M, Aiona M. Comparison of three ankle-foot orthosis configurations for children with spastic hemiplegia. Dev Med Child Neurol. 2001;43(6):371-8.

25. Thompson N, Taylor T, McCarthy K, Cosgrove A, Baker R. Effect of a rigid ankle-foot orthosis on hamstring length in children with hemiplegia. Dev Med Child Neurol. 2002;44(1):51-7.

26. Winters T, Gage J, Hicks R. Gait patterns in spastic hemiplegia in children and young adults. J Bone Joint Surg Am. 1987;69(3):437-41.

27. Rosenbaum P, Walter S, Hanna S, Plisano R, Russell D, Raina P, et al Development and reliability of a system to classify gross motor functions in children with cerebral palsy. JAMA. 2002;288(11):1357-63.

28. Lucareli PRG, Lima MdO, Lucarelli JGdA, Lima FPS. Changes in joint kinematics in children with cerebral palsy while walking with and without a floor reaction ankle-foot orthosis. Clinics. 2007;62(1):63-8.

29. Smith PA, Hassani S, Graf A, Flanagan A, Reiners K, Kuo KN, Roh JY, Harris GF. Brace evaluation in children with diplegic cerebral palsy with a jump gait pattern. JBJS. 2009 Feb 1;91(2):356-65.
30. Romkes J, Hell AK, Brunner R. Changes in muscle activity in children with hemiplegic cerebral palsy while walking with and without ankle-foot orthoses. Gait Posture. 2006;24(4):467-74.

31. Van Gestel L, Molenaers G, Huenaerts C, Seyler J, Desloovere K. Effect of dynamic orthoses on gait: a retrospective control study in children with hemiplegia. Dev Med Child Neurol. 2008;50(1):63-7.

32. Butler P, Thompson N, Major R. Improvement in walking performance of children with cerebral palsy: preliminary results. Dev Med Child Neurol. 1992;34(7):567-76

33. Brunner R, Meier G, Ruepp T. Comparison of a stiff and a springtype ankle-foot orthosis to improve gait in spastic hemiplegic children. J Pediatr Orthop B. 1998;18(6):719-26.

34. Rethlefsen S, Kay R, Dennis S, Forstein M, Tolo V. The effects of fixed and articulated ankle-foot orthoses on gait patterns in subjects with cerebral palsy. J Pediatr Orthop B. 1999;19(4):470-4

35. Buckon CE, Thomas SS, Jakobson-Huston S, Moor M, Sussman M, Aiona M. Comparison of three ankle-foot orthosis configurations for children with spastic diplegia. Dev Med Child Neurol. 2004;46(09):590-8.

36. Smiley SJ, Mielke C, Johnston R, Park C, CO GJO. A comparison of the effects of solid, articulated, and posterior leaf-spring ankle-foot orthoses and shoes alone on gait. Orthopedics. 2002;25(4):411

37. Thomas SS, Buckon CE, Jakobson-Huston S, Sussman MD, Aiona MD. Stair locomotion in children with spastic hemiplegia: the impact of three different ankle foot orthosis (AFOs) configurations. Gait Posture. 2002;16(2):180-7.

38. Hsu JD, Michael J, Fisk J. AAOS atlas of orthoses and assistive devices: Elsevier Health Sciences; 2008.

39. Rosenthal RK, Deutsch SD, Miller W, Schumann W, Hall J. A fixedankle, below-the-knee orthosis for the management of genu recurvation in spastic cerebral palsy. J Bone Joint Surg . 1975;57(4):545-7.

40. Butler P, Farmer S, Stewart C, Jones P, Forward M. The effect of fixed ankle foot orthoses in children with cerebral palsy. Disabil Rehabil Assist Technol. 2007;2(1):51-8.

41. Lam W, Leong J, Li Y, Hu Y, Lu W. Biomechanical and electromyographic evaluation of ankle foot orthosis and dynamic ankle foot orthosis in spastic cerebral palsy. Gait Posture. 2005;22(3):189-97.

42. Wilson H, Haideri N, Song K, Telford D. Ankle-foot orthoses for preambulatory children with spastic diplegia. J Pediatr Orthop. 1997;17(3):370-6.

43. Sumiya T, Suzuki Y, Kasahara T. Stiffness control in posterior-type plastic ankle-foot orthoses: Effect of ankle trimline Part 2: Orthosis characteristics and orthosis/patient matching. Prosthet Orthot In. 1996;20(2):132-7.

44. Major R, Hewart P, Macdonald A. A new structural concept in moulded fixed ankle foot orthoses and comparison of the bending stiffness of four constructions. Prosthet Orthot Int. 2004;28(1):44-8.

45. Higgins JP, Green S. Cochrane handbook for systematic reviews of interventions: Wiley Online Library; 2008.

46. Churchill AJ, Halligan PW, Wade DT. Relative contribution of footwear to the efficacy of ankle-foot orthoses. Clin Rehabil. 2003;17(5):553-7.

47. Ross K, Bowers R. Best practice statement: use of ankle-foot orthoses following stroke. InBritish Association of Prosthetists and Orthotists Annual Conference. 2009:1-60.

48. Brehm M-A, Harlaar J, Schwartz M. Effect of ankle-foot orthoses on walking efficiency and gait in children with cerebral palsy. J Rehabil Med. 2008;40(7):529-34

49. Manca M, Ferraresi G, Cosma M, Cavazzuti L, Morelli M, Benedetti M. Gait Patterns in Hemiplegic Patients with Equinus Foot Deformity. Biomed Res Int. 2014;2014.

50. Rouse EJ, Hargrove LJ, Akhtar A, Kuiken TA. Validation of methods for determining ankle stiffness during walking using the Perturberator robot. InBiomedical Robotics and Biomechatronics (BioRob), 2012 4th IEEE RAS \& EMBS International Conference on 2012 Jun 24 (pp. 1650-1655). IEEE.

51. Cakar E, Durmus O, Tekin L, Dincer U, Kiralp M. The ankle-foot orthosis improves balance and reduces fall risk of chronic spastic hemiparetic patients. Eur J Phys Rehabil Med. 2010;46(3):363-8.

52. Kerkum YL, Brehm MA, Buizer AI, van den Noort JC, Becher JG, Harlaar J. Defining the mechanical properties of a spring-hinged ankle foot orthosis to assess its potential use in children with spastic cerebral palsy. J Appl Biomech. 2014;30:728-31. 
Appendix 1. Scoring items of the PEDro scale

Items of the PEDro scale

External validity

1 The eligibility criteria were specified.

Internal and statistical validity

2 The subjects were randomly allocated to groups.

3 The allocation was concealed

4 The groups were similar at baseline on most important prognostic indicators.

$5 \quad$ There was a blinding of all subjects.

$6 \quad$ There was blinding of all therapists who administered the therapy.

$7 \quad$ There was blinding of all assessors who measured at least one key outcome.

8 Measurements of at least one key outcome were obtained from more than $85 \%$ of the subjects initially allocated to groups

9 All subjects from whom outcome measures were available received the treatment or control condition as allocated; where this was not the case, data for at least one key outcome were analysed by "intention to treat".

10 The results of between-group statistical comparisons are reported for at least one key outcome.

11 The study provides both point measurements and measurements of variability for at least one key outcome. 